\title{
USE OF A RAPID MICROWAVE FIXATION TECHNIQUE FOR IMMUNOCYTOCHEMICAL DEMONSTRATION OF TUMOR NECROSIS FACTOR, INTERLEUKIN-1 $\alpha$, AND INTERLUEKIN-1 $\beta$ IN ACTIVATED HUMAN PERIPHERAL MONONUCLEAR CELLS.
}

\author{
Nobuhiko HARUNA, Takushi MONDEN, Hideki MORIMOTO, \\ Masahiro MUROTANI, Toshio YAGYU, Hirohito NAGAOKA, \\ TAKAShI SHIMANO AND TAKESAdA MORI
}

The Second Department of Surgery, Osaka University Medical School, 1-1-50 Fukushima, Fukushima-ku, Osaka 553

\begin{abstract}
In the present paper, we demonstrated the presence of various cytokines in activated mononuclear cells immunocytochemically by using a rapid microwave (MW) fixation technique. Cytospin preparations of human peripheral blood mononuclear cells activated by a biological response modifier, OK-432, in vitro, were quickly fixed by $\mathrm{MW}$ irradiation in a diluted aldehyde solution consisting of $0.05 \%$ glutaraldehyde, $2 \%$ formaldehyde, $0.025 \%$ calcium chloride and $0.1 \mathrm{M}$ sodium cacodylate in phosphate-buffered saline (PBS) (pH 7.4). In the stimulated cells, tumor necrosis factor- $\alpha$ (TNF), interleukin-1 $\alpha$ (IL-1 $\alpha$ ), and interleukin-1 $\beta$ (IL-1 $\beta$ ) were clearly demonstrated immunocytochemically by using the specific antibodies for each cytokine.

Immunoreactivity for TNF appeared in the cells after $1.5 \mathrm{hr}$ of stimulation, and diffuse cytoplasmic stain was achieved after $24 \mathrm{hr}$ of stimulation.

IL-1 $\alpha$ appeared in both cytoplasms and nuclei of the stimulated cells after $3 \mathrm{hr}$. The distribution of cytoplasmic IL-1 $\alpha$ suggested the association with the cytoplasmic membrane. With $I L-1 \beta$, a strong diffuse stain was obtained after $6 \mathrm{hr}$, and indicated that the IL-1 $\beta$ was concentrated in cytoplasm.

Rapid MW fixation makes it possible to fix metabolically labile cytokines which have been difficult to localize in routinely fixed specimens. The method is expected to be a valuable tool in the study of cell biology.
\end{abstract}

To make the best use of biological investigations, the cells and tissues must be examined under conditions as close to that of the living state as possible. The aim of cell and tissue fixation is to provide the materials in a life-like state, both morphologically and chemically. Although routine methods of fixation using various chemical fixatives have proven valuable, recent progress in molecular biology has increased the demands for investigation of very labile substances which may be difficult to fix by the usual methods of fixation.

The various cytokines are among the subjects of such investigation because they play an important role in the induction of immune responses. The in situ detection of these cytokines in the mononuclear cells, however, may not always be successful because the amount of each cytokine produced is very small, and many of them are known to be rapidly processed [14] and secreted without intracellular retention [12].

To overcome these difficulties, we have developed a rapid MW-fixation techni- 
que. Microwave irradiation of biological materials was first described by Mayers in 1970 [13], and is known to be useful for tissue fixation [3, 6] because the MW energy, which is absorbed and converted into heat within the tissue, can allow fixation in as brief a time as 10 to $20 \mathrm{sec}$. Recently, Login et al reported an improved method of fixation in which MW energy was used in conjunction with chemical cross-linking agents to fix cells and tissues, and demonstrated the superiority of the fixation method for the preservation of morphological details and antigenic substances in situ [7-10].

In the present study, we investigated the localization of each cytokine as TNF, IL- $1 \alpha$, and IL- $1 \beta$ in activated mononuclear cells by using the MW-fixation technique described by Login et al with some modification. Our results demonstrated that the MW-fixation method allows immunolocalization of various cytokines which have previously been difficult to detect in routinely fixed samples, and that the method will contribute to the analysis of the mechanism of immune responses.

\section{MATERIALS AND METHODS}

Reagents and antibodies

A multi-cytokine inducer, OK-432 (heat- and penicillin-treated lyophilized powder of the Su-strain of Streptococcus pyogenese) [4, 5, 15, 19, 20], was supplied by Chugai Pharmaceutical Co., Ltd. (Tokyo, Japan). One Klinishe Einheit (KE) corresponds to $0.1 \mathrm{mg}$ of dried streptococci.

Anti OK-432 antibody was prepared by immunizing rabbits several times with $2.5 \mathrm{mg}$ of OK-432. Antiserum was completely absorbed with strains B and C of streptococcus pyogenese. Anti TNF rabbit antibody was purchased from Genzyme Co., Ltd. (Kneeland, Boston). Anti IL- $1 \alpha$ and anti IL- $1 \beta$ rabbit antibodies $[17,18]$ were provided by Otsuka Pharmaceutical Co., Ltd. (Osaka, Japan).

For negative controls, antibodies neutralized with recombinant human TNF, IL$1 \alpha$, or IL- $1 \beta$ respectively were prepared as follows: $1 \mathrm{ml}$ of the antibody diluted $1: 200$ was applied to $250 \mathrm{mg}$ of Tresyl-activated Sepharose 4B affinity column (Pharmacia Fine Chemical, Uppsala, Sweden) coupled with $1 \mathrm{mg}$ of recombinant TNF, IL- $1 \alpha$, or IL-1 $\beta$. The absorbed antibodies were obtained after $3 \mathrm{hr}$ incubation at room temperature.

Preparation and stimulation of mononuclear cells

Peripheral mononuclear cells were isolated from heparinized venous blood by lymphocyte separation medium (LSM) (Organon Teknika Corporation, Durtham, North Carolina). The mononuclear cells were suspended at $2 \times 10^{6} / \mathrm{ml}$ in RPMI1640 medium (Biken, Osaka, Japan) containing 10\% fetal bovine serum (FBS) (Hyclone Laboratories, Logan, Utah), $2 \mathrm{mM}$ glutamine (Gibco, Grand Island, NY), $100 \mathrm{U}$ of penicillin and $100 \mathrm{mg} / \mathrm{ml}$ of streptomycin (Gibco). The adherent cells were selected in a 6 -well plastic tissue culture cluster. After a $2 \mathrm{hr}$ conditioning period, OK-432 was added to the cells at the final concentration of $0.1 \mathrm{KE} / \mathrm{ml}$. The treated cells were incubated for $24 \mathrm{hr}$ at $37^{\circ} \mathrm{C}$. The cells without activation by OK-432 were used as controls.

Microwave fixation and Immunocytochemical Staining

The cells were collected and attached to the glass slides by Auto smear CF-12D (Sakura, Tokyo, Japan) at $800 \mathrm{rpm}, 4 \mathrm{~min}$ and then air dried. Cytospin specimens were rapidly fixed by MW irradiation according to the method of Login et al with 


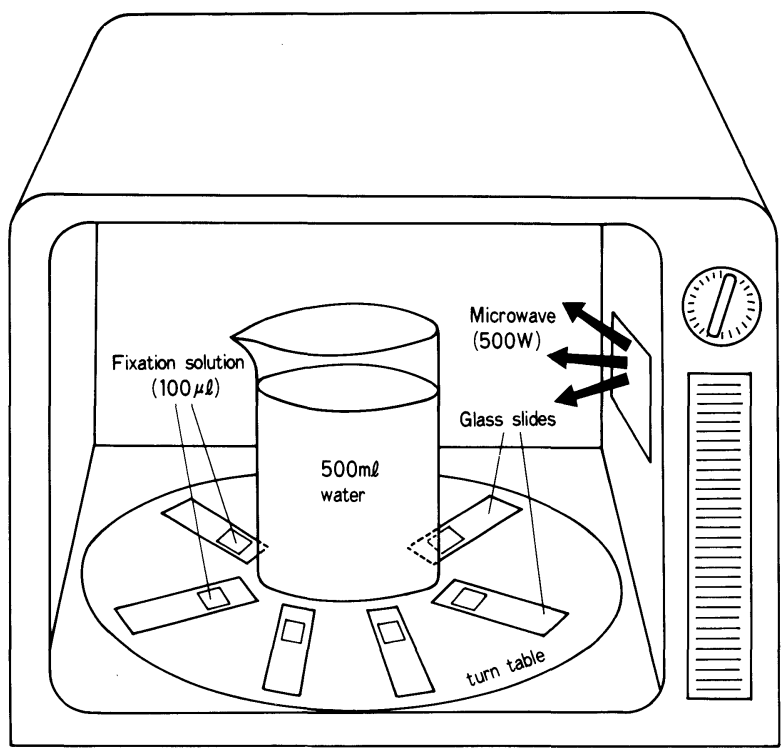

Fig. 1. A schematic view of microwave irradiation. Cytospin preparations of stimulated mononuclear cells are overlaid with $100 \mu \mathrm{l}$ of the fixative, and immediately irradiated for $10 \mathrm{sec}$ with a power setting of 500 watts.

modifications [7-10]. The cells were overlaid with $100 \mu \mathrm{l}$ of solution containing $0.05 \%$ glutaraldehyde, $2 \%$ formaldehyde, $0.025 \%$ calcium chloride and $0.1 \mathrm{M}$ sodium cacodylate in phosphate-buffered saline (PBS, pH 7.4). The glass slides were then placed horizontally, six at a time, in a domestic MW oven (National, Model NEM3) within a $10 \mathrm{~cm}$ radius from the center. A $500 \mathrm{ml}$ water bath was placed in the center of the oven, and the samples were immediately irradiated with $2,450 \mathrm{MHz}$ of MW for $10 \mathrm{sec}$, with a power setting of 500 Watts (Fig. 1).

The slides were then washed in PBS and treated first with $0.3 \%$ hydrogen peroxide in absolute methanol to inactivate any remaining peroxidase activity; then with $3 \%$ normal goat serum for $15 \mathrm{~min}$ at room temperature to block nonspecific binding. For the first antibodies, anti OK-432 antibody and anti TNF antibody, anti IL- $1 \alpha$ antibody and anti IL-1 $\beta$ antibody were applied to the slides respectively at a dilution of $1: 1000$, and incubated overnight at $4^{\circ} \mathrm{C}$. The slides were again washed in PBS and overlaid with biotinylated goat anti-rabbit IgG and incubated for $20 \mathrm{~min}$ at room temperature. After this, the slides were incubated with peroxidase labeled streptavidin for $20 \mathrm{~min}$, and specific immunostain was visualized by reaction with $0.02 \% 3,3^{\prime}$ diaminobenzidine tetrahydrochloride (Wako, Osaka, Japan) solution in $0.05 \mathrm{M}$ Tris$\mathrm{HCl}$ ( $\mathrm{pH} 7.6$ ) containing $0.002 \%$ hydrogen peroxide for 3 to $7 \mathrm{~min}$. Finally, the slides were counterstained with hematoxylin and mounted for light microscopic examination. To confirm the specificity of the immunostaining, neutralized antibodies against each cytokine were used as negative controls. 


\section{RESULTS}

Mononuclear cells showed phagocytosis of OK-432 in their cytoplasm by incubation in the medium containing $0.1 \mathrm{KE} / \mathrm{ml}$ of OK-432. A few spots of immunostain for OK-432 appeared in the cytoplasm of the mononuclear cells after $1.5 \mathrm{hr}$ of stimulation (Fig. 2a). Longer incubation caused increased immunostaining (Fig. 2b), and diffuse cytoplasmic stain was achieved after $24 \mathrm{hr}$ of stimulation with OK-432 (Fig. 2c). The untreated controls showed no immunoreactivity.

TNF was demonstrated after $1.5 \mathrm{hr}$ of stimulation, when a tiny spot of immunostain for TNF appeared in the perinuclear cytoplasm of mononuclear cells with concave nuclei (Fig. 3a). The spots increased in number with time (Fig. 3b), and diffuse cytoplasmic staining was achieved after $24 \mathrm{hr}$ of stimulation (Fig. 3c).

IL- $1 \alpha$ was detected in the mononuclear cells after $3 \mathrm{hr}$ of stimulation. It was localized in the periphery of the cytoplasm, suggesting that it was present in a membrane-associated form, and the nuclei of some of the cells were also stained (Fig. 4). For IL- $1 \beta$, the strongest staining was obtained after $6 \mathrm{hr}$ of OK-432 stimulation. The staining was diffuse and indicated that the cytokine was mainly concentrated in the cytoplasm (Fig. 5).

The spcificity of immunostaining for each cytokine was confirmed in negative controls stained with neutralized antibodies (Fig. 6).

\section{DISCUSSION}

The immunocytochemical study of cytokines is expected to give valuable informa-

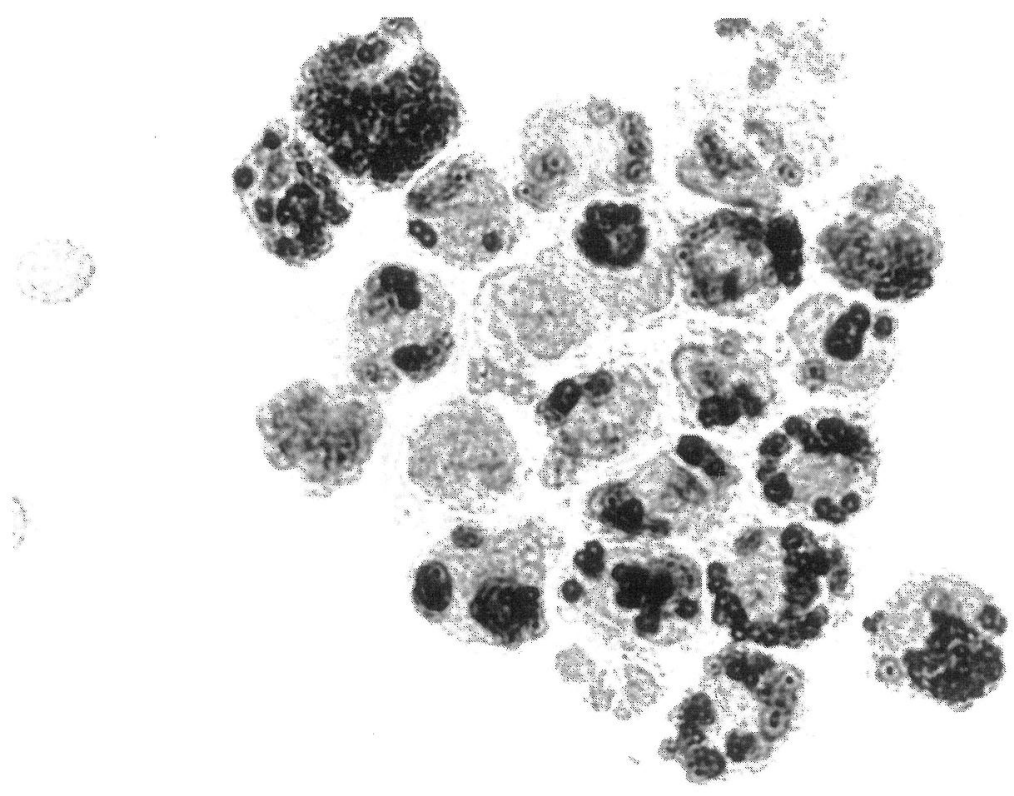

FIG. 2a 


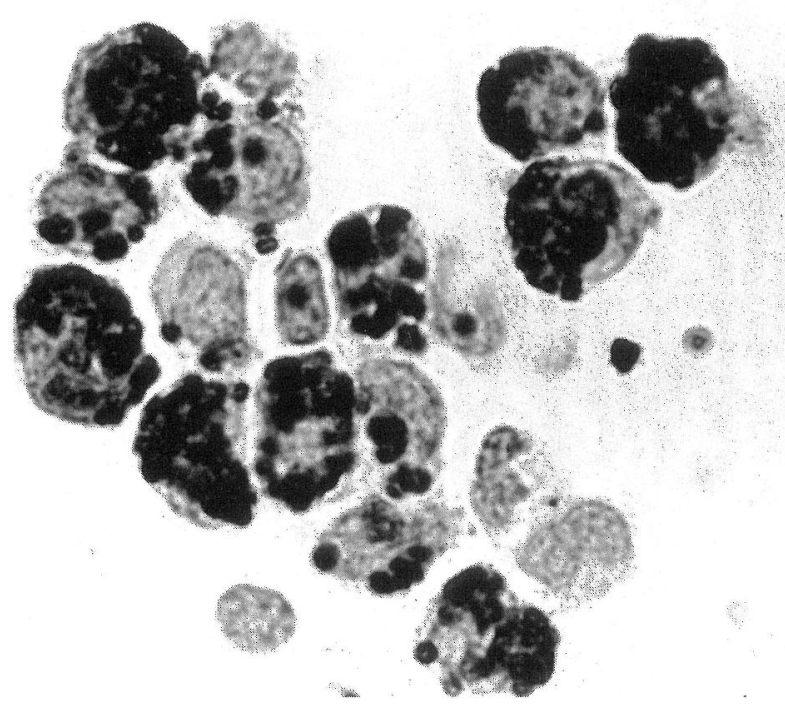

FIG. 2b

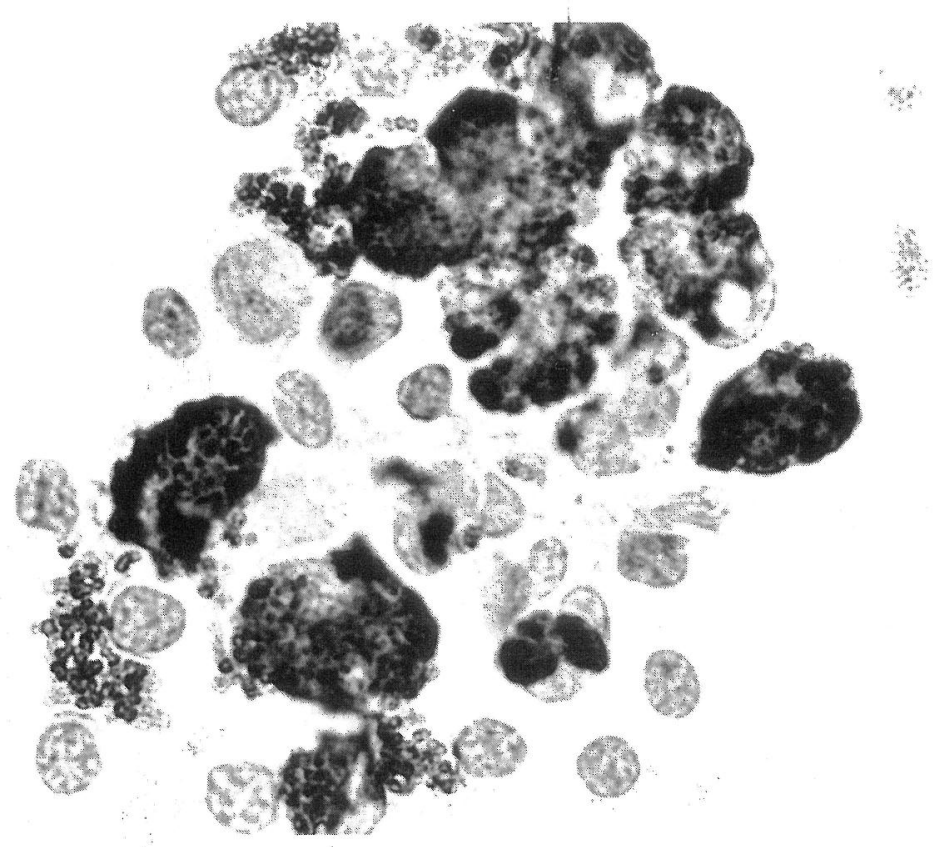

Fig. 2c

FIGs. 2a-c. Immunocytochemistry of mononuclear cells stained for OK-432. a. $1.5 \mathrm{hr}$ after stimulation. b. $6 \mathrm{hr}$ after stimulation. c. $24 \mathrm{hr}$ after stimulation with OK-432. 


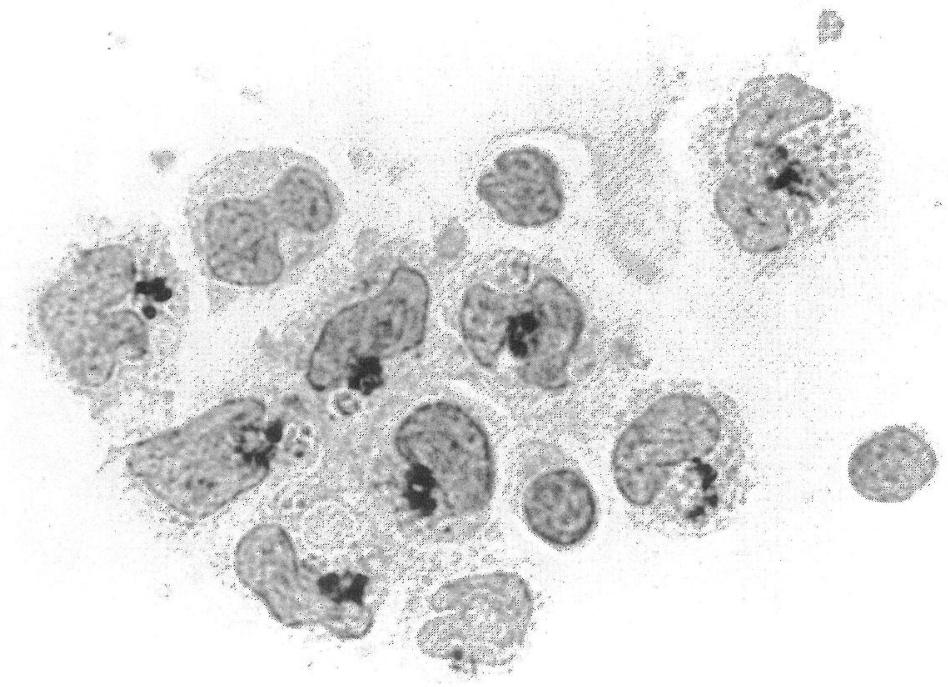

Fig. 3a

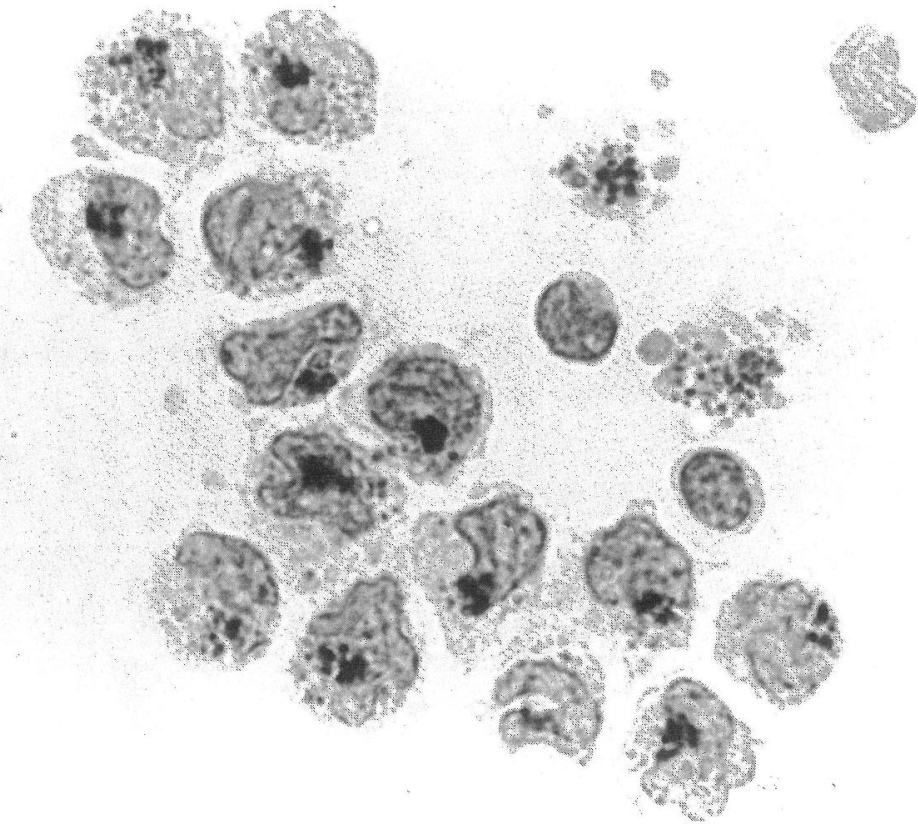

FIG. 3b 


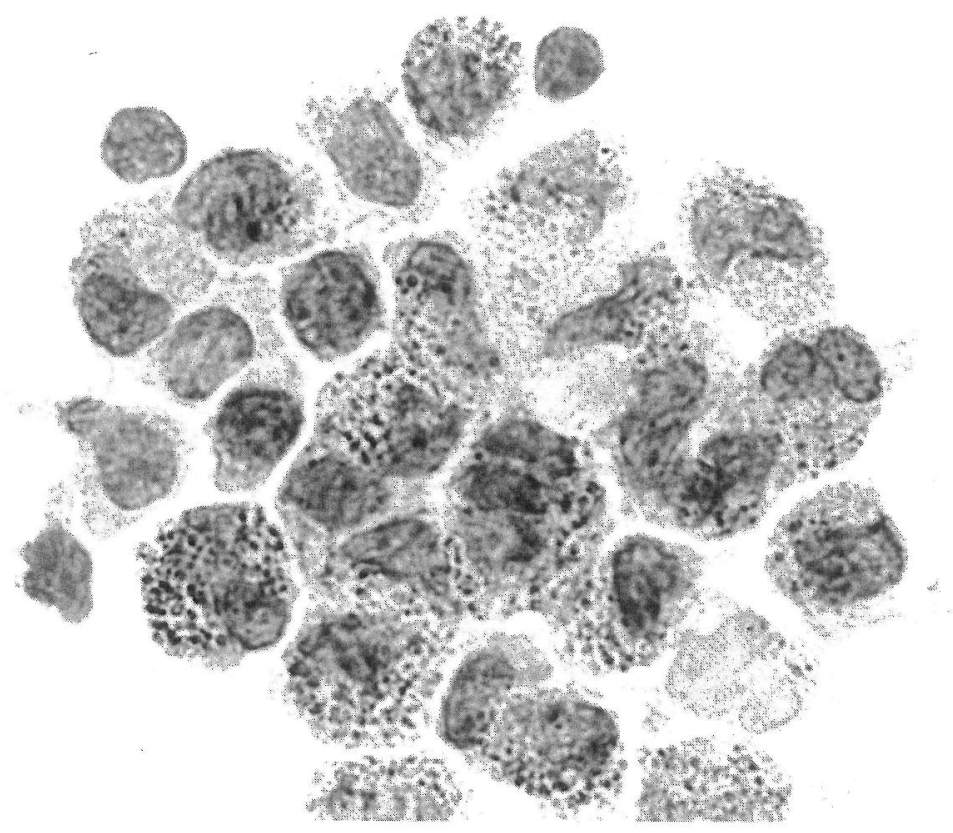

FIG. 3c

FIGS. 3a-c. Immunocytochemical staining for TNF. a. a tiny spot of immunostain appears in the perinuclear cytoplasm of mononuclear cells stimulated with OK-432 for $1.5 \mathrm{hr}$. b. The spots increase in number after $6 \mathrm{hr}$ of stimulation. c. diffuse cytoplasmic stain is achicved after $24 \mathrm{hr}$ of stimulation.

FIG. 4. Immunostain for IL- $1 \alpha$ in the mononuclear cells stimulated with OK- 432 for $3 \mathrm{hr}$. IL- $1 \alpha$ is localized at the cytoplasmic periphery (arrow head), and the nuclei of some of the cells are also stained. 


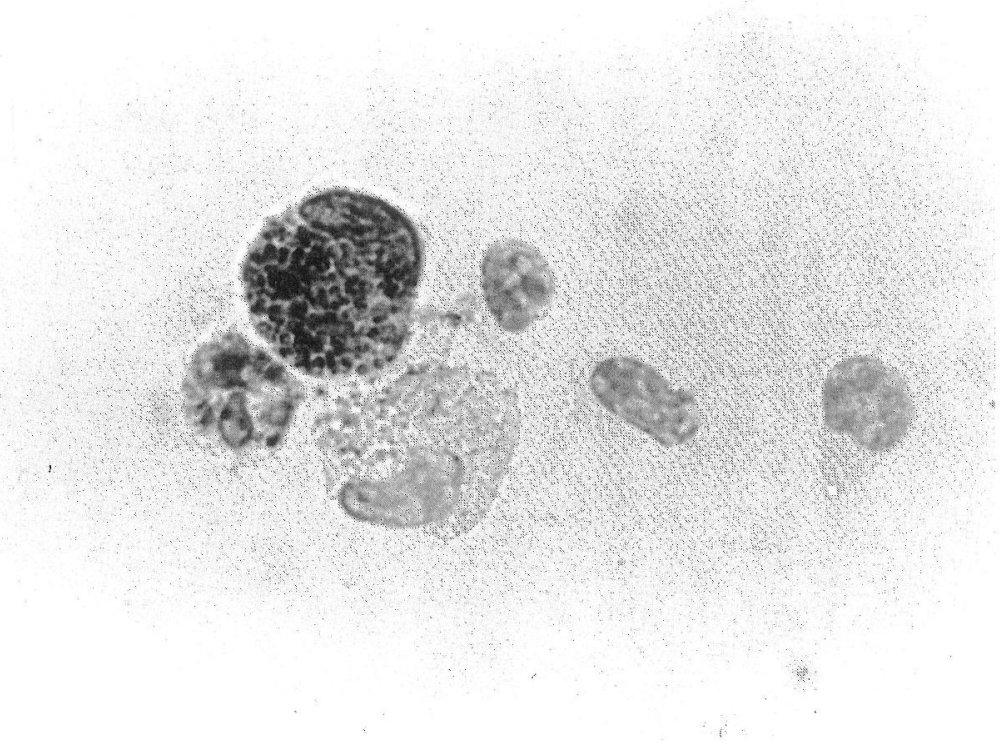

FIG. 5. Immunostain for IL-1 $\beta$. IL-1 $\beta$ is localized at the cytoplasm of the mononuclear cells stimulated with OK-432 for $6 \mathrm{hr}$.

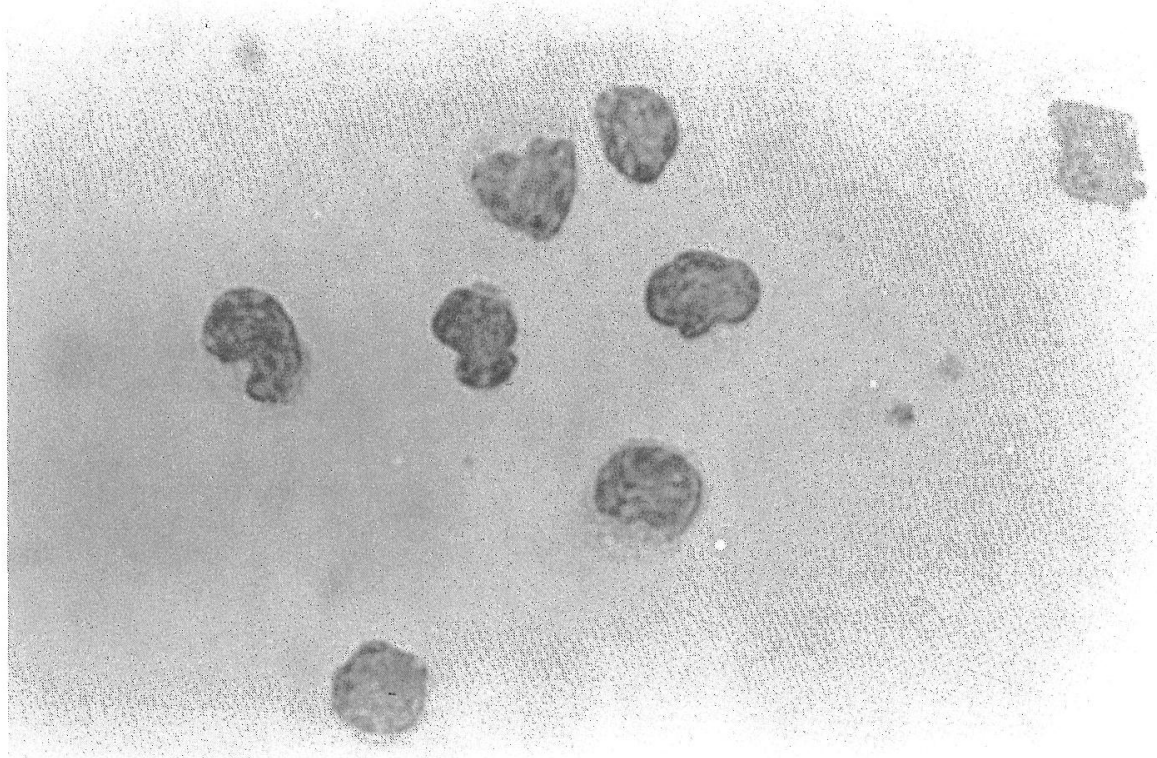

FIG. 6. Immunostain for TNF is completely abolished when the antibody is absorbed with recombinant form of TNF. 
tion on the analysis of immune responses. The in situ detection of TNF and IL-1, however, is difficult because TNF has been reported to be rapidly secreted without intracellular retention [12], and IL-1, which does not contain any hydrophobic region [11], is apt to leach out of the cytoplasm during fixation. Several reports have described the immunocytochemical localization of TNF and IL-1. Chensue et al [2] demonstrated membrane-associated TNF as well as cytoplasmic TNF in murine macrophages stimulated with lipopolysaccharide (LPS). They prepared activated macropahges by immersion fixation in $4 \%$ paraformaldehyde for 5 min with or without postfixation in absolute methanol. In our study, we could not demonstrate a membane association of TNF probably because the pretreatment of the cells with methanol damaged the membrane, but we think that a much stronger staining and more detailed intracytoplasmic localization of TNF could be achieved by MW fixation. As shown in Fig. 3, changes in the staining pattern for TNF during OK-432 stimulation were clearly demonstrated in the MW-fixed mononuclear cells. After stimulation for $1.5 \mathrm{hr}$, a tiny spot of dye appeared next to the concave nucleus, and then spots increased in number and spread to the cytoplasm with longer stimulation. These findings agreed well with the results of quantitation analysis of released TNF in the supernatants of stimulated cells by enzyme immunoassay (data not shown).

The superiority of antigen preservation in MW fixation was also demonstrated in the detection of IL-1. Our immunocytochemical findings on IL- $1 \beta$, which gave a diffuse cytoplasmic staining, supported the findings of Singer et al [16] who showed that IL- $1 \beta$ is present mainly in the cytoplasmic ground substances, but is absent from the plasma membrane of human monocytes stimulated with LPS. In contrast, IL- $1 \alpha$ is considered to be associated with plasma membrane [1], and the localization of IL- $1 \alpha$ in the present study, in which immunostaining for IL- $1 \alpha$ was observed in the periphery of the cytoplasm, supported this. However, some of the cells showed nuclear stain for IL- $1 \alpha$, and in this case the staining was not non-specific because it was completely abolished in the negative controls stained with the antibody absorbed with recombinant IL-1 $\alpha$. Although further analysis on the subcellular distribution of cytokines is needed, our MW fixation technique seems to provide valuable information on the mechanisms of cytokine production by mononuclear cells.

\section{ACKNOWLEDGMENTS}

This work was supported by Grant-in-Aid for Cancer Research, and Science Research from the Ministry of Education, Science and Culture, Japan.

\section{REFERENCES}

1. Beuscher, H. U., Fallon, R.J. and Colten, H.: Macrophage membrane interleukin-1 regulates the expression acute phase proteins in human hepatoma Hep 3B cells. J. Immunol. 139; 1896-1990, 1987.

2. Chensue, S. W., Remick D. R., Shmyr-Forsch, C., Beals, T. and Kunkel, S. L.: Immunohistochemical demonstration of cytoplasmic and membrane-associated tumor necrosis factor in murine macrophages. Am. J. Pathol. 133; 564-572, 1988.

3. Hopwood, D., Ramsay, J., Milne, G. and Kerrr, M.: Microwave fixation: its potential for routine techniques, histochemistry, immunocytochemistry and electron microscopy. Histochem. J. 16; 1171-1191, 1984. 
4. Kato, M. and Kakehi, R.: Anti-tumor therapy in a patient with metastatic renal cell carcinoma by inducing endogenous production of tumor necrosis factor. Lancet II; 270, 1985.

5. Kokunai, I., Shimano, T., Sekimoto, K., Takeda, T., Kobayashi, T., Yayoi, E., Yamamoto, A. and Mori, T.: Induction of tumor necrosis factor by administration of OK-432 in cancer patients. J. Clin. Lab. Immunol. 21; 169-171, 1986.

6. Leong, A. S.-Y., Daymon, M. E. and Milios, J.: Microwave irradiation as a form of fixation for light and electron microscopy. J. Pathol. 146; 313-321, 1985.

7. Login, G. R. and Dvorak, A. M.: Microwave energy fixation for electron microscopy. Am.J. Pathol. 120; 230-243, 1985.

8. Login, G. R., Galli, S. J., Morgan, G. E., Arizono, N., Schwartz, L. S. and Dvorak, A. M.: Rapid microwave fixation of rat mast cell. I. Localization of granule chymase with an ultrastructual postembedding immunogold technique. Lab. Invest. 57; 592-599, 1987.

9. Login, G. R., Schnitt, S. J. and Dvorak, A. M.: Rapid microwave fixation of human tissues for light microscopic immunoperoxidase identification of diagnostically useful antigens. Lab. Invest. 57; 585-584, 1987.

10. Login, G. R., Stavinoha, W. B. and Dvorak, A. M.: Ultrafast microwave energy fixation for electron microscopy. J. Histochem. Cytochem. 34; 381-387, 1986.

11. March, C. J., Mosley, B., Larsen, A., Gerretti, D. P., Braedt, G., Price, V., Gillis, S., Henney, C. S., Kronheim, S. R., Grabstein, K., Conlon, P. J., Hopp, T. P. and Cosman, D.: (1985). Cloning, sequence and expression of two distinct human interleukin-1 compelementary DNAs. Nature 315; 641-647, 1985.

12. Marmenout, A., Fransen, L., Tavernier, J., Van Der Heyden, J., Tizard, R., Kawashima, E., Shaw, A., Johnson, M.-J., Semon, D., Muller, R., Ruysschaert, M.-R., Vliet, V. A. and Fiers, W.: Molecular cloning and expression of human tumor necrosis factor and comparison with mouse tumor necrosis factor. Eur. J. Biochem. 152; 515-522, 1985.

13. Mayers, C. P.: Histological fixation by microwave heating. J. Clin. Path. 23; 273-275, 1970.

14. Pennica, D., Nedwin, G. E., Hayflick, J. S., Seeburg, P. H., Derynck, R., Palladino, M. A., Kohr, W. J., Aggarwal, B. B. and Goeddel, D. V.: Human tumour necrosis factor: precursor structure, expression and homology to lymphotoxin. Nature 312; 724-729, 1984.

15. Sekimoto, M., Komunai, I., Shimano, T., Kobayashi, T., Takeda, T., Haruna, N., Yamamoto, A. and Mori, T.: Production of tumor necrosis factor (TNF) by monocytes from cancer patients and healthy subjects induced by OK- 432 in vitro, and its augmentation by human interferon gamma. J. Clin. Lab. Immunol. 27; 115-120, 1988.

16. Singer, I. I., Scott, S., Hall, G. L., Limjuko, G., Chin, J. and Schmidt, J. A.: Interleukin-1 $\beta$ is localized in the cytoplasmic ground susbtance but largely absent from the Golgi apparatus and plasma membranes of stimulated human monocytes. J. Exp. Med. 167; 389-407, 1988.

17. Tanaka, K., Ishikawa, E., Ohmoto, Y. and Hirai, Y.: Sandwich enzyme immunoassay for human interleukin- $1 \alpha$ produced in vitro by peripheral blood mononuclear cells. Clin. Chim. Acta 170; 97-104, 1987.

18. Tanaka, K., Ishikawa, E., Ohmoto, Y. and Hirai, Y.: Sandwich enzyme immunoassay for human interleukin-1b (hIL-1b) in urine. Clin. Chim. Acta 166; 237-246, 1987.

19. Uchida, A. and Hoshino, T.: Clinical studies on cell-mediated immunity in patients with malignant disease. 1. Effect of immunotherapy with OK-432 on lymphocyte subpopulation and phytomitogen responsiveness in vitro. Cancer 45; 476-483, 1980.

20. Yamamoto, A., Nagamura, M., Usami, H., Sugawara, Y., Watanabe, M., Niitsu, Y. and Urushizaki, I.: Release of tumor necrosis factor (TNF) into mouse peritoneal fluids by OK432, a streptococcal preparation. Immunopharmacol. 11; 79-86, 1986. 